\title{
ANALISIS PREDIKSI KONDISI KESULITAN KEUANGAN DENGAN MENGGUNAKAN RASIO LIKUIDITAS, PROFITABILITAS, FINANCIAL LEVERAGE DAN ARUS KAS
}

\author{
Dwiyani Sudaryanti*, Annisa Dinar \\ Universitas Islam Malang, Sekolah Tinggi IImu Ekonomi Asia Malang
}

INFO ARTIKEL

DOI: 10.32812/jibeka.v13i2.120

ISSN-P: 0126-1258

ISSN-E: 2620-875X

Keywords: liquidity, profitability, financial leverage, cash flow, financial distress

\begin{abstract}
Financial distress is pre condition before bankruptcy, so prediction of the condition is very important that will help company to decide policy in the future. This study wants to test variables which are believed as the financial distress predictors. Research population is mine coal companies listed on Bursa Efek Indonesia. With purposive sampling as sampling technique, there are 15 companies as sample with 60 financial statements as the data. This research use regression logistic as the research method. The result shows that liquidity ratio, financial leverage, and cash flow can not be used as financial distress predictor. however profitability ratio can. This research implies that financial performance in funding doesn't always correlate with operational performance. Next researches are needed with different variables and population so that the result can be generalized.
\end{abstract}

\section{ABSTRAK}

Kesulitan keuangan (financial distress) merupakan pra kondisi sebelum terjadi kebangkrutan, sehingga prediksi akan kondisi tersebut akan membantu perusahaan dalam mempersiapkan kebijakan yang tepat. Penelitian ini bertujuan menganalisis rasio keuangan yang bisa digunakan sebagai prediktor terjadinya kesulitan keuangan pada perusahaan. Populasi penilitian adalah perusahaan pertambangan batu bara yang terpublikasi. Teknik pengambilan sampel dengan menggunakan purposive sampling, dan diperoleh 15 perusahaan atau 60 sampel laporan keuangan. Data tersebut dianalisis menggunakan metode regresi logistik. Rasio likuiditas, financial leverage, dan arus kas, berdasar hasil pengujian, tidak dapat digunakan untuk memprediksi kondisi kesulitan keuangan perusahaan sampel. Sedangkan rasio profitabilitas dapat digunakan untuk memprediksi. Implikasi penelitian ini adalah perlunya pengguna laporan keuangan memisahkan kinerja pendanaan dengan kinerja operasional. Penelitian selanjutnya diharapkan mampu menambah variabel penelitian dan menggunakan populasi penelitian yang berbeda agar hasil penelitian dapat digeneralisasi. 


\section{Pendahuluan}

Financial Distress atau kesulitan keuangan merupakan istilah untuk menyebut kondisi suatu perusahaan yang sedang dalam kondisi tidak bisa menunaikan kewajiban keuangannya sesuai yang ditetapkan sebelumnya. Kondisi financial distress menjadi pra kondisi sebelum terjadinya kebangkrutan suatu perusahaan Kondisi kesulitan keuangan antara lain ditandai oleh terjadinya laba negatif yang dialami perusahaan secara berturutturut. Akibatnya, perusahaan tidak memiliki sumber dana yang memadai untuk memenuhi kewajiban yang harus segera dipenuhinya (perusahaan mengalami kebangkrutan). Untuk selanjutnya, istilah kondisi kesulitan keuangan dan financial distress akan digunakan secara bergantian.

Terdapat beberapa faktor yang menyebabkan perusahaan dalam keadaan kesulitan keuangan. Jauch dan Glueck (2004:87) membagi menjadi 3 penyebab financial distress, yaitu faktor umum, faktor eksternal perusahaan dan faktor internal perusahaan. Faktor umum penyebab financial distress adalah faktor yang terjadi secara umum pada suatu masyarakat, yang terdiri atas sektor usaha, sektor sosial, sektor teknologi dan sektor pemerintah. Faktor eksternal adalah faktor penyebab yang berasal dari spesifik pada suatu perusahaan yang berasal dari luar perusahaan, yang terdiri atas sektor pelanggan, sektor pemasok, dan sektor pesaing. Sedangkan faktor penyebab financial distress internal adalah faktor yang berasal dari internal perusahaan, berasal dari keputusan dan kebijakan yang tidak tepat yang diambil di masa lalu, serta kegagalan manajemen membuat sesuatu yang diperlukan pada saat dibutuhkan.

Sebagai sebuah pra kondisi dari jatuhnya perusahaan ke dalam kondisi bangkrut, informasi mengenai financial distress menjadi informasi yang sangat penting bagi sebuah perusahaan. Hal tersebut mendorong dilakukannya banyak penelitian yang bertujuan melakukan pengujian dengan menggunakan beragam variabel dan beragam sampel penelitian untuk mendapatkan informasi tersebut. Penelitian-penelitian tersebut antara lain Almilia dan Kristijadi (2003), Mas'ud dan Srengga (2015), Platt dan Platt (2002), Widarjo dan Setiawan (2009), dan Widati dan Bayu (2015).

Terdapat hasil yang beragam dari penelitian-penelitian yang telah dilakukan untuk memprediksi financial distress. Hal tersebut menjadi motivasi penelitian ini untuk melakukan penelitian dengan topik yang sama, namun dengan variabel dan obyek penelitian yang berbeda. Diharapkan, penelitian ini bisa memberikan kontribusi penting dalam menunjukkan variabel yang bisa dgunakan untuk meprediksi kondisi financial distress.

Penelitian ini menggunakan obyek penelitian perusahaan pertambangan karena adanya kondisi umum yang menjadi penyebab terjadinya financial distress pada industri tersebut. Krisis ekonomi pada tahun 2015 membuat permintaan akan komoditas tambang menurun yang berakibat harga jual komoditas tambang anjlok. Di Indonesia, menurunnya harga komoditas tambang secara drastis serta menurunnya permintaan bahan tambang dari China memberikan dampak buruk bagi kinerja keuangan perusahaan tambang di Indonesia. Krisis ekonomi ini mengakibatkan beberapa perusahaan tambang khususnya tambang batu bara tidak beroperasi. (Kompas.com, 2015). Dengan karakteristik tersebut, penelitian ini yakin perusahaan pertambangan merupakan obyek penelitian yang tepat untuk bisa mencapai tujuan penelitian. 


\section{Metode Penelitian}

\section{Teori Sinyal}

Signalling theory atau teori sinyal yang dikembangkan oleh Ross (1977) menjelaskan mengenai dorongan atau alasan suatu perusahaan memberikan informasi tertentu kepada pihak luar. Teori tersebut dilatarbelakangi oleh asumsi bahwa pihak manajemen atau internal perusahaan memiliki informasi yang lebih lengkap mengenai kondisi perusahaan dibandingkan informasi yang dimiliki pihak luar. Berdasarkan kondisi tersebut, perusahaan akan berusaha menggunakan informasi yang mereka miliki untuk memberikan pesan kepada pihak luar mengenai kinerja yang mereka capai. Pesan tersebut akan direspon sebagai sinyal baik atau sinyal buruk oleh pihak luar, sehingga sinyal tersebut dapat direspon pasar dalam menilai kualitas perusahaan serta dapat membantu perusahaan mengambil kebijakan untuk memperbaiki kinerja perusahaan. Prediksi financial distress akan memberikan sinyal bagi manajemen perusahaan pertambangan untuk mengambil keputusan tentang kinerja mereka, dan bagi pihak luar dalam memprediksi keberlangsungan kerjasama mereka dengan perusahaan.

\section{Pengaruh likuiditas terhadap financial distress.}

Rasio likuiditas adalah rasio-rasio yang digunakan untuk mengukur pemenuhan kewajiban lancar perusahaan dengan menggunakan asset lancarnya. Menurut Hani (2015:121), likuiditas adalah kemampuan perusahaan memenuhi kewajiban keuangan yang harus segera ditunaikan atau yang sudah tiba tenggat waktunya. Semakin besar nilai rasio likuiditas, hal tersebut menunjukkan bahwa perusahaan mampu memenuhi kewajiban lancarnya dengan menggunakan aktiva lancar yang dimilikinya. Dengan demikian, terdapat kemungkinan yang kecil bahwa perusahaan tersebut akan mengalami kondisi financial distress.

Current ratio menurut Harahap (2011:301) menunjukkan perbandingan jumlah aktiva lancar dalam menutupi jumlah kewajiban lancar. Semakin besar hasil perbandingan, menunjukkan kemampuan perusahaan yang semakin tinggi memenuhi kewajiban lancarnya. Hasil penelitian Widarjo dan Setiawan (2009) menunjukkan bahwa likuiditas memberikan pengaruh yang signifikan pada kondisi financial distress perusahaan. Semakin besar rasio menunjukkan kemungkinan perusahaan mengalami kondisi financial distress yang semakin kecil. Sehingga, hipotesis pertama penelitian ini adalah:

$\mathrm{H} 1$ = likuiditas memiliki pengaruh signifikan terhadap financial distress.

\section{Pengaruh profitabilitas terhadap financial distress.}

Rasio profitabilitas, menurut Kasmir (2012:196), adalah rasio yang digunakan untuk mengukur kemampulabaan perusahaan. Dengan kata lain, rasio tersebut juga menunjukkan efektifitas manajemen. Perusahaan dengan rasio profitabilitas yang tinggi berarti memiliki kemampuan keuangan yang cukup untuk memenuhi kebutuhan operasionalmya. Jumlah laba yang besar akan menunjukkan bahwa perusahaan tidak akan terkena kondisi financial distress. Penelitian ini menggunakan tingkat kembalian atas asset atau return on assets (ROA) untuk mengukur tingkat pendapatan perusahaan. Angka rasio yang semakin tinggi menunjukkan semakin tinggi pendapatan yang diperoleh oleh perusahaan, yang dapat diasumsikan operasional perusahaan berjalan dengan baik. Ketika pendapatan perusahaan yang diperoleh mampu membiayai operasional perusahaan serta memenuhi kewajiban perusahaan, maka kecil kemungkinan perusahaan akan mengalami kondisi financial distress. 
Penelitian Harjanti (2011) menunjukkan ROA merupakan prediktor kondisi financial distress pada perusahaan perbankan. ROA yang semakin besar memiliki arti semakin kecilnya peluang perusahaan mengalami kondisi financial distress. Berdasarkan uraian diatas maka hipotesis kedua penelitian adalah:

$\mathrm{H} 2$ : profitabilitas memiliki pengaruh signifikan pada kondisi financial distress.

\section{Pengaruh financial leverage pada financial distress}

Terdapat beberapa kondisi yang membuat perusahaan harus memilih utang sebagai sumber dana perusahaan mereka. Meskipun pilihan tersebut memiliki konsekuensi, namun konsekuensi tersebut diperhitungkan masih lebih kecil daripada manfaat yang diperoleh dari penggunaan utang. Perhitungan itulah yang disebut sebagai financial leverage. Menurut Martono dan Harjito (2008:295) rasio leverage merujuk pada aktiva tetap dan sumber dana yang digunakan oleh perusahaan, dengan konsekuensi berupa biaya tetap atau beban tetap yang harus dikeluarkan perusahaan akibat penggunaan tersebut. Indikator dalam penelitian untuk mengukur rasio financial leverage adalah debt to equity ratio (DER). Semakin besar rasio financial leverage maka semakin besar pula kewajiban yang dimiliki perusahaan. Besarnya kewajiban tetap tersebut membawa pada besarnya kemungkinan perusahaan berada dalam kondisi financial distress. Penelitian Almilia dan Kristijadi (2003) membuktikan bahwa rasio financial leverage dapat menjadi prediktor kondisi financial distress. Berdasarkan uraian sebelumnya, diajukan hipotesis ketiga penelitian sebagai berikut:

H3: financial leverage memiliki pengaruh signifikan pada financial distress.

\section{Pengaruh arus kas pada financial distress.}

Rasio arus kas menunjukkan perbandingan jumlah aktiva yang digunakan dalam menghasilkan arus kas yang berasal dari aktivitas operasi. Rasio arus kas juga menunjukkan kemampuan perusahaan membayar kewajiban lancer dengan menggunakan arus kas bersihnya. Sehingga, penelitian ini meyakini bahwa rasio arus kas bisa digunakan sebagai prediktor kondisi financial distress perusahaan. Arus kas dari kegiatan operasi dapat menjadi indikator apakah sebuah perusahaan mampu menghasilkan kas dari kegiatan operasinya. Perusahaan yang memiliki arus kas yang besar, artinya memiliki sumber dana yang besar pula untuk mendanai kegiatan operasionalnya sehingga perusahaan memiliki kemungkinan yang kecil untuk mengalami kondisi financial distress. Mas'ud dan Srengga (2015) menunjukkan bahwa arus kas bisa menjadi prediktor adanya financial distress perusahaan. Sehingga, hipotesis keempat yang diajukan penelitian ini adalah:

$\mathrm{H} 4$ : arus kas memiliki pengaruh signifikan pada financial distress.

Gambar 1. Kerangka konseptual

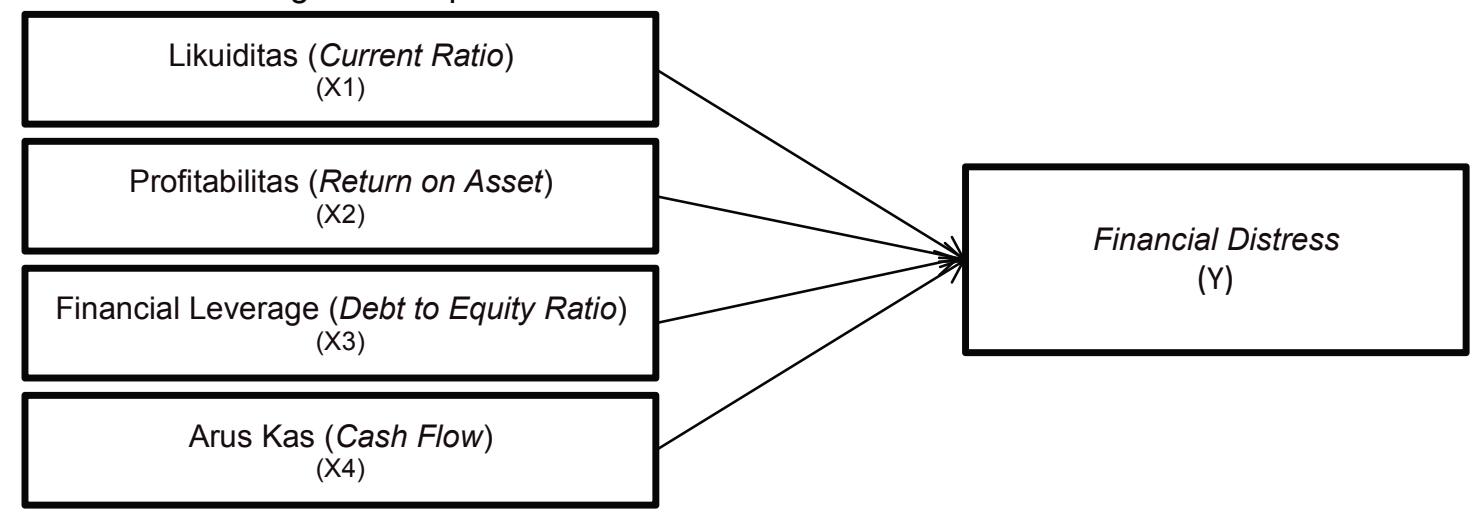


Penelitian ini termasuk dalam jenis penelitian kuantitatif. Penelitian kuantitatif adalah penelitian yang menitik-beratkan pada pengukuran dan analisis hubungan sebab akibat antara bermacam-macam variabel (Bahri, 2018:11). Populasi penelitian adalah semua perusahaan sub sektor pertambangan batu bara yang terpublikasi di Bursa Efek Indonesia selama tahun 2014-2017. Sedangkan sampel penelitian diambil dengan menggunakan metode purposive sampling, dengan kriteria pemilihan sampel adalah perusahaan sub sektor pertambangan batu bara yang terdaftar di bursa efek Indonesia periode 2014-2017, yang konsisten menerbitkan laporan keuangan secara lengkap, dan bisa diakses melalui website Bursa Efek Indonesia www.idx.co.id, website perusahaan, dan sumber lain, dengan satuan moneter rupiah. Berdasarkan kriteria tersebut, dari total populasi 22 perusahaan, terpilih sampel sebanyak 15 perusahaan.

Variabel terikat adalah variabel yang keberadaannya dipengaruhi variabel bebas (Bahri, 2018:132). Variabel terikat dalam penelitian yakni financial distress diukur dengan teknik dummy variable, dengan ketentuan:

$Y=1 ;$ perusahaan mengalami financial distress

$\mathrm{Y}=0$; perusahaan tidak mengalami financial distress

Perusahaan mendapat nilai $Y=1$ jika perusahaan tersebut mengalami laba bersih negatif selama dua tahun atau lebih secara berturut-turut. Jika perusahaan mengalami laba negative kurang dari 2 tahun secara berturutan, maka nilai $Y=0$.

Likuiditas diukur dengan current ratio (CR) sebagai berikut:

$$
\text { Current Ratio }=\frac{\text { AktivaLancar }}{\text { Kewajiban Lancar }} X 100 \%
$$

Profitabilitas diukur dengan return on assets (ROA sebagia berikut:

$$
\text { Returnon Assets }=\frac{\text { Laba Bersih }}{\text { TotalAktiva }} X 100 \%
$$

Financial leverage diukur dengan debt to equity ratio (DER) sebagai berikut:

$$
\text { Debt\& Equity Ratio }=\frac{\text { Total Kewajiban }}{\text { Total Ekuitas }} X 100 \%
$$

Arus kas operasi diukur dengan rumus sebagai berikut:

$$
\text { Arus KasOperasi }=\frac{\text { Arus Kas Operasi }}{\text { Kewajiban Lancar }} X 100 \%
$$

Analisis regresi logistik digunakan sebagai metode analisis karena data yang digunakan bersifat non-metrik pada variabel dependennya, sedangkan pada variabel independenya berupa campuran data metrik dan data non-metrik. Regresi logistik ditujukan untuk menguji 
kemungkinan variabel dependen dalam penelitian dapat diprediksi oleh variabel independennya (Ghozali, 2009:71).

$$
\left.P\left(\frac{F D}{1-F D}\right)=B o+B 1 L K+B 2 P R O+B 3 L V+B 4 A K\right]
$$

Model yang digunakan dalam penelitian ini adalah:

Dimana:

$\mathrm{P} \quad=$ probabilitasperusahaan mengalami financial distress.

$\mathrm{FD}=$ financial distress

Bo = konstanta

$\mathrm{B}=$ koefisien regresi

LK = likuiditas

PRO = profitabilitas

$\mathrm{LV}=$ financial leverage

$\mathrm{AK}=$ arus kas

Penentuan kriteria dalam pengambilan keputusan adalah:

Jika signifikansi $<0.05$ maka hipotesis diterima.

Jika signifikansi $>0.05$ maka hipotesis ditolak

\section{Hasil Penelitian dan Pembahasan}

Penyajian statistik deskriptif dalam penelitian adalah untuk mengetahui gambaran umum data penelitian yang digunakan. Hal tersebut disajikan dalam table 1 berikut ini:

Tabel 1. Statistik Deskriptif Penelitian

\begin{tabular}{|l|r|r|r|r|r|}
\hline & $\mathrm{N}$ & Minimum & Maximum & Mean & Std. Deviation \\
\hline LK & 60 &, 063 & 6,914 & 1,71945 & 1,364750 \\
PRO & 60 &,- 644 &, 394 &, 03075 &, 169721 \\
FL & 60 & $-7,174$ & 11,909 & 1,21867 & 2,955009 \\
AK & 60 & $-1,827$ & 2,046 &, 52892 &, 615798 \\
Valid N & 60 & & & & \\
(listwise) & & & & & \\
\hline
\end{tabular}

Tabel 1 di atas menunjukkan, secara umum data penelitian memiliki simpangan yang sangat besar. Ditunjukkan oleh nilai tertinggi dan tertinggi masing-masing variabel yang sangat lebar. Selain itu, data relatif heterogen, yang ditunjukkan oleh standar deviasi yang cukup besar, lebih besar dari nilai rata-ratanya.

Kelayakan model regresi logistik penelitian ditunjukkan dari nilai Hosmer and Lemeshow Goodness of fit. Menurut Ghozali (2011:341) jika nilainya lebih besar dari 0,05 maka tidak memiliki beda yang signifikan antara model dengan nilai observasinya, atau model dapat diterima dan dapat memprediksi nilai observasinya. Tabel 2 berikut menunjukkan hasil nilai Hosmer and Lemeshow Goodness of fit. 
Tabel 2. Nilai Hosmer and Lemeshow

\begin{tabular}{|c|c|c|c|}
\hline Step & Chi-square & $d f$ & Sig. \\
\hline 1 & 3,799 & 8 & 875, \\
\hline
\end{tabular}

Nilai sebesar 3,799 dengan probabilitas signifikansi 0,875 menunjukkan nilainya jauh diatas 0,05 sehingga dapat disimpulkan model regresi penelitian dapat diterima.

Hasil regresi logistik dengan menggunakan SPSS ditunjukkan oleh tabel 3 berikut:

Tabel 3. Variable in The Equation

\begin{tabular}{|ll|r|r|r|r|r|r|}
\hline & & \multicolumn{1}{|c|}{ B } & \multicolumn{1}{c|}{ S.E. } & \multicolumn{1}{c|}{ Wald } & df & \multicolumn{1}{c|}{ Sig. } & Exp(B) \\
\hline Step & LK & $-1,354$ & 1,352 & 1,003 & 1 &, 317 &, 258 \\
$1^{a}$ & PRO & $-49,251$ & 19,183 & 6,592 & 1 &, 010 &, 000 \\
& FL &, 153 &, 215 &, 507 & 1 &, 477 & 1,166 \\
& AK &, 175 & 2,101 &, 007 & 1 &, 933 & 1,192 \\
& Constan &, 008 & 1,367 &, 000 & 1 &, 995 & 1,008 \\
\hline & t & & & & & & \\
\hline
\end{tabular}

Hasil perhitungan pada Tabel 3 digunakan untuk menyusun persamaan model regresi logistik sebagai berikut:

$$
P\left(\frac{F D}{1-F D}\right)=0,008-1,354 L K-49,251 \text { PRO }+0,153 F L+0,175 \text { AK }
$$

Penentuan pengambilan keputusan pada model regresi logistik ditentukan dari nilai signifikansi variabel independennya. Hasil pengujian hipotesis pada tabel 3 menunjukkan bahwa hipotesis 1, 3 dan 4 dalam penelitian ini ditolak karena memiliki nilai signifikansi di atas 0,05 . Sedangkan hipotesis ke 2 , dengan nilai signifikansi sebesar 0,010 , disimpulkan bisa diterima karena memiliki nilai signifikansi di bawah 0,05.

\section{Pengaruh likuiditas pada kondisi financial distress}

Hasil penelitian menununjukan likuiditas tidak memiliki pengaruh yang signifikan pada kondisi financial distress, ditunjukkan oleh tingkat signifikansi 0,317. Likuiditas perusahaan sampel rata-rata sebesar 1,7 (lihat tabel 1) yang artinya perusahaan memiliki kemampuan menunaikan kewajiban jangka pendeknya dengan baik. Sayangnya, kinerja yang baik dalam hal pendanaan jangka pendek tidak terkait dengan kemampuan perusahaan dalam mengelola dana tersebut. Perusahaan sampel adalah perusahaan batubara yang memiiki karakteristik bersifat jangka panjang dari sisi perputaran modal kerjanya maupun investasi asset tetapnya (padat modal). Sehingga, kinerja jangka pendek seperti likuditas tidak bisa dikaitkan secara langsung dengan kemampulabaan perusahaan, yang menjadi variabel operasional dari kondisi kesulitan keuangan perusahaan. Hasil penelitian ini mendukung hasil penelitian Mas'ud dan Srengga (2015), namun tidak mendukung hasil penelitian Widarjo dan Setiawan (2009). Penelitian Widarjo dan Setiawan (2009) menggunakan sampel perusahaan otomotif yang memiliki karakteristik perputaran modal kerja yang relatif cepat, sehingga kinerja jangka pendek seperti likuiditas akan berpengaruh pada kemampuan mendapatkan laba sebagai variabel operasional financial distress. 


\section{Pengaruh profitabilitas pada kondisi financial distress}

Hasil penelitian menunjukkan profitabilitas memberikan pengaruh signifkan pada kondisi financial distress dengan tingkat signifikansi sebesar 0,01. Pengaruh tersebut bersifat negatif. Perusahaan sampel menunjukkan bahwa laba negatif yang dimiliki oleh beberapa perusahaan mempengaruhi kondisi keuangan perusahaan. Semakin kecil kemampuan perusahaan dalam menghasilkan keuntungan mempengaruhi kondisi keuangan yang mengakibatkan terjadi peluang semakin besar terjadinya kondisi financial distress. Hasil penelitian ini didukung oleh hasil penelitian Harjanti (2011), Widarjo dan Setiawan (2009) serta Mas'ud dan Srengga (2015).

\section{Pengaruh financial leverage pada kondisi financial distress}

Hasil penelitian menunjukkan bahwa financial leverage tidak berpengaruh signifikan terhadap kondisi financial distress dengan tingkat signifikansi sebesar 0,477. Rasio financial leverage yang diukur menggunakan DER menunjukkan besarnya modal perusahaan yang dibiayai menggunakan kewajiban yang dimiliki. Perusahaan sampel menunjukkan bahwa kewajiban yang tinggi masih dapat dikelola dengan baik oleh perusahaan sebagai sumber dana operasional perusahaan. Kewajiban tinggi yang dimiliki perusahaan tidak dapat menyebabkan perusahaan terkena kondisi financial distress. Hasil penelitian ini didukung oleh Widarjo dan Setiawan (2009) serta penelitian Mas'ud dan Srengga (2015), namun tidak didukung oleh hasil penelitian Almilia dan Kristijadi (2003). Ketidaksamaan hasil penelitian ini dengan penelitian Almilia dan Kristijadi (2003) disebabkan oleh perbedaan dalam penggunaan variabel operasional financial distress yang lebih ketat (dua kriteria) dan jenis industri perusahaan yang dipilih sebagai sampel, yaitu perusahaan manufaktur, yang memiliki karakteristik perputaran modal yang berbeda dari perusahaan batu bara.

\section{Pengaruh arus kas pada kondisi financial distress}

Hasil penelitian menunjukkan arus kas tidak memiliki pengaruh yang signifikan pada kondisi financial distress, dengan tingkat signifikansi sebesar 0,933. Arus kas dari operasi menjadi indikator apakah perusahaan dapat melunasi pinjaman, membayar dividen, menjalankan kegiatan operasional, dan melakukan investasi baru dari kegiatan operasional yang dilakukan perusahaan. Perusahaan sampel menunjukkan bahwa meskipun rasio arus kas berada dibawah angka 1 (satu), namun hal tersebut tidak menjadi predictor adanya kondisi financial distress. Perusahaan masih mampu mengelola arus kas yang dimiliki untuk operasional perusahaan sehingga perusahaan masih mampu membayar kewajiban lancar yang dimiliki. Hasil penelitian ini tidak sejalan dengan penelitian Mas'ud dan Srengga (2015). Perbedaan tersebut disebabkan oleh perbedaan karakteristik perputaran modal kerja pada jenis industri yang digunakan sebagai sampel. Perusahaan batubara adalah perusahaan dengan perputaran modal kerja yang relatif lama, sehingga tidak terkait secara langsung dengan kinerja yang bersifat jangka pendek, seperti arus kas. Berbeda dari perusahaan manufaktur yang menjadi sampel pada penelitian Mas'ud dan Srengga (2015).

\section{Kesimpulan}

Likuiditas, financial leverage dan arus kas tidak memiliki pengaruh signifikan pada kondisi financial distress. Analisis menunjukan bahwa hal tersebut disebabkan oleh karakteristik perputaran modal kerja yang relatir lama yang dimiliki oleh perusahaan sampel, sehinnga kinerja yang bersifat jangka pendek sebagaimana yang ditunjukan oleh tiga 
variable dalam hipotesis 1, 3 dan 4 tidak memiliki pengaruh pada kinerja operasional, yaitu perolehan laba, sebagai variabel operasional kondisi financial distress. Hal tersebut menunjukkan bahwa kinerja pendanaan (perolehan dana) dan kinerja operasional (penggunaan dana) tidak selalu terkait langsung, tergantung karakteristik perusahaan yang dijadikan sampel penelitian.

Terdapat banyak peluang bagi peneliti selanjutnya untuk memperbaiki penelitian ini. Perbedaan tahun penelitian, perbedaan jenis industry sebagai obyek penelitian, dan perbedaan variable operasional yang digunakan menjadi langkah yang diperlukan untuk mendapatkan informasi yang lebih baik dari kriteria indikator kondisi kesulitan keuangan perusahaan.

\section{Daftar Pustaka}

Almilia, Luciana S., dan E. Kristijadi. 2003. Analisis Rasio Keuangan Untuk Memprediksi Kondisi Financial Distress Perusahaan Manufaktur Yang Terdaftar Di Bursa Efek Jakarta. Jurnal Akuntansi dan Auditing Indonesia. Vol. 7 No. 2. hal 183-206.

Bahri, Syaiful. 2018. Metodologi Penelitian Bisnis (Lengkap dengan Teknik Pengolahan Data SPSS). Edisi Pertama, Penerbit Andi, Yogyakarta.

Ekonomi Lesu, 125 Perusahaan Batu Bara Bangkrut, 5000 Orang Kena PHK. 2015. www.nasional.kompas.com

Ghozali, Imam. 2009. Aplikasi Analisis Multivariate dengan program SPSS. Penerbit UNDIP, Semarang.

Ghozali, Imam. 2011. Statistik Non Parametrik. Penerbit UNDIP, Semarang.

Hani, Syafrida. 2015. Teknik Analisia Laporan Keuangan. Penerbit Umsu Press, Medan.

Harahap, Sofyan Syafri. 2011. Teori Akuntansi (Edisi Revisi). Penerbit PT. Raja Grafindo Persada, Jakarta.

Harjanti, Reny Sri, 2011. Analisis Pengaruh Rasio Rasio Keuangan Terhadap Prediksi Kebangkrutan Bank (Studi Pada Bank Umum Swasta Devisa Yang Terdaftar Di Bank Indonesia Tahun 2004 - 2008), Skripsi. Universitas Diponegoro.

Industri Tambang Global dan Nasional Ada di Ujung Tanduk. 2015. www.ekonomi.kompas.com

Jauch, Lawrence R., dan William F. Glueck. 2004. Strategic Management and Business Policy. 9th Edition. McGraw-Hill Inc.

Kasmir. 2012. Analisis Laporan Keuangan. Penerbit PT. Raja Grafindo Persada, Jakarta.

Mas'ud, Imam dan RM Srengga 2015. Analisis Rasio Keuangan Untuk Memprediksi Kondisi Financial Distress Perusahaan Manufaktur yang Terdaftar di BEl. Jurnal Akuntansi Universitas Jember. Vol 10, hal 139-154

Martono dan Harjito. 2008. Manajemen Keuangan. Penerbit Ekonisia, Yogyakarta. 
Platt Harlan D, dan Platt Marjorie B. 2002. Predicting Corporate Financial Distress:

Reflections on Choice-Based Sample Bias. Journal of Economics and Finance. Vol. 26 No. 2. pp. 184-197

Ross, Stephen A. 1977. The Determination of Financial Structure: The Incentive-Signalling Approach. The Bell Journal of Economics, Vol 8 No 1 pp 23-40

Widarjo, W. dan Doddy Setiawan. 2009. Pengaruh Rasio Keuangan Terhadap Kondisi Financial Distress Perusahaan Otomotif, Jurnal Bisnis dan Akuntansi, Vol 11 No 2 hal 107-119

Wilopo. 2001. Prediksi Kebangkrutan Bank. Jurnal Riset Akuntansi Indonesia. Vol. 4 No. 2. Hal. 184-198. 